\title{
Diagnostyka psychopedagogiczna problemów przystosowawczych i(e)migrantów o charakterze transkulturowym
}

\begin{abstract}
Streszczenie
Artykuł prezentuje propozycję modelu diagnostyki psychopedagogicznej problemów i(e)migranckich o charakterze transkulturowym. Oparcie tego typu modeli i procedur na głównych założeniach współczesnych teorii transkulturowości wynika z tego, iż jest to jedna z najbardziej znamiennych charakterystyk współczesności, jak również z faktu, iż proces transkulturacji wśród tejże grupy społecznej jest obecnie szczególnie dynamiczny. W prezentowanym modelu (z uwagi na praktyczny i innowacyjny charakter pedagogiki oraz w odpowiedzi na postulowane przez ekspertów ds. migracji potrzeby modyfikacji modeli i procedur diagnostycznych) uwzględniono również specyfikę symptomów postępu i blokad procesów przystosowawczych i(e)migranta, w odniesieniu do poszczególnych faz procesów jego adaptacji i integracji, w odniesieniu do sfer: społecznej, psychicznej, dydaktycznej i opiekuńczo-wychowawczej.
\end{abstract}

\section{Słowa kluczowe:}

diagnoza psychopedagogiczna, diagnoza o charakterze transkulturowym, model diagnozy, transkulturowość, migracje, fazy przystosowania, postęp i blokady procesu przystosowania

1 Marta Guziuk-Tkacz, Wydział Nauk Społecznych, Uniwersytet Warmińsko-Mazurski w Olsztynie, Polska, e-mail: marta.guziuk-tkacz@uwm.edu.pl, ORCID ID: https://orcid.org/ 0000-0002-3829-6025. 


\begin{abstract}
The article presents a proposal of the psycho-pedagogical transcultural diagnosis model of migrant's problems. A ground to this type of models and procedures, based on the main assumptions of contemporary theories of transculturalism, creates a consequence of the fact, that it is one of the most significant characteristics of our times, as well as the fact that the transculturation process among this social group is currently a very dynamic one. In the model presented hereby (due to the practical and innovative nature of pedagogy and in response to the need of diagnostic models and procedures modification postulated by migration experts) the specificity of progress and blockades symptoms of immigrants' adaptation were also taken into account - with regard to phases of adaptation and integration processes in the social, psychological, didactic, care and educational spheres.
\end{abstract}

\title{
Keywords:
}

psycho-pedagogical diagnosis, transcultural diagnosis, model of diagnosis, transculturality, migrations, stages of adaptation, progress, or blockades of adaptation processes

\section{WPROWADZENIE}

Współczesne nam czasy charakteryzują zjawiska i procesy takie jak globalizacja wyrażająca się w „wielości powiązań i wzajemności oddziaływań państw i społeczeństw, tworzących obecny system światowy” (McGrew, 1992, s. 28), zacieranie się różnic kulturowych, intensyfikacja współdziałania i współzależności pomiędzy państwami, regionami i subregionami, dynamiczny postęp technologiczny, funkcjonowanie człowieka w dwóch paralelnych przestrzeniach - geograficznej i cyberprzestrzeni - i wynikająca z tego wielość, a zarazem kompresja relacji czasoprzestrzennych (Maśloch, 2005, s. 19), znaczny wzrost dynamiki ruchów migracyjnych - tzw. płynne transmigracje (Okólski, 2009) oraz transkulturowość. Ostatnia z wymienionych charakterystyk współczesności rozumiana jako „płynność, mieszanie się, ustawiczne interakcje i zacieranie się granic społeczno-kulturowych i świadomościowych” (Nikitorowicz, 2015, s. 183) to konsekwencja przekraczania granic narodowych w procesach kulturotwórczych i interpolacji tychże procesów (Steingress, 2010, s. 7), jak również „przeniesienia wartości właściwych określonej kulturze na grunt innej kultury” (Kostyrko, 2004, s. 22).

Efektami typowej dla współczesności dyfuzji kulturowej i transkulturacji są: powstanie „nowej różnorodności” (Welsch, 1998a, s. 217) i nowego typu wielości oraz heterogeniczności „różnych kultur i form życia” (Welsch, 1998a, s. 217), 
hybrydyzacja kultur, funkcjonowanie człowieka współczesności poza jedną, przypisaną mu kulturą (Steingress, 2010, s. 10), a tym samym poczucie przynależności do różnych typów zbiorowości i kultur (Sobecki, 2018, s. 96), poczucie pluralnego subiektywizmu i pluralnej podmiotowości.

Wolfgang Welsch, autor najbardziej rozbudowanej i spójnej teorii transkulturowości, podkreśla także rangę typowej dla współczesności, transwersalnej wymiany kulturowej i procesu łagodzenia różnic kulturowych (Welsch, 1995, s. 44; Welsch, 1998a, s. 213), jak również wagę syntezy wielu różnych układów i form kulturowych i powstawania nowych jakości kulturowych - „sieci kulturowych” (Welsch, 1998a, s. 59) w skali makro- i mikrospołecznej.

Wspomniane cechy współczesności, jak również masowa komunikacja i wzrost dynamiki ruchliwości społecznej oraz kontaktów o charakterze transnarodowym rzutują silnie na jakość teraźniejszych migracji oraz funkcjonowanie psychospołeczne współczesnych i(e)migrantów w nowych realiach kraju przyjmującego.

Pedagogika, podobnie jak inne nauki społeczne o charakterze praktycznym, powinna podążać za zmianami i wymogami współczesności, gdyż tylko elastyczność i dostosowanie oferty dydaktyczno-wychowawczej, opiekuńczo-pomocowej i terapeutycznej do jej wyzwań gwarantuje adekwatność tychże ofert do aktualnych potrzeb, oczekiwań i możliwości człowieka XXI wieku.

Jakie zatem wyzwania stoją przed współczesną diagnostyką pedagogiczną problemów i(e)migranckich?

Odpowiedzią na to pytanie są zarówno wnioski z analiz wyników przeprowadzonych przez autorkę artykułu czteroletnich badań sondażowych o charakterze międzynarodowym, wśród 1715 dorosłych Polaków (w różnych grupach wiekowych i o różnym poziomie wykształcenia), jak również wśród 571 cudzoziemców i ekspertów do spraw migracji z 72 krajów. Dobór heterogenicznej - ze względu na korzenie kulturowe - próby do badań zapewnił uzyskanie opinii od osób reprezentujących różnorodne wzory kulturowe. Z kolei uzyskanie opinii ekspertów do spraw migracji z różnych obszarów kulturowych na temat stosowanych aktualnie modeli diagnostyki problemów i(e)migranckich gwarantowało profesjonalne oceny tychże modeli i ich empiryczną weryfikację, jak również opis pożądanych zmian i modyfikacji w tym obszarze.

Badani jednogłośnie uznali transkulturowość za jedną z głównych cech współczesności (opinię tę podzieliło aż 87,8\% ankietowanych). Zdaniem 88,9\% respondentów „,usieciowienie życia społecznego” i wynikające z tego częste i systematyczne komunikowanie się osób z różnych obszarów kulturowych wpływa na tworzenie się kultur wewnętrznie (choć w różnym stopniu) zróżnicowanych. Aż 89,9\% badanych obcokrajowców i 60,9\% badanych Polaków uważa także siebie 
za osobę, której tożsamość kulturowa jest wewnętrznie zróżnicowaną i kreowaną w licznych relacjach z przedstawicielami innych wzorów kulturowych (Bauman, 1998; Misiejuk, 2018 i in). Badani eksperci do spraw migracji uznali nadto, iż transkulturowe tożsamości - typowe dla człowieka XXI wieku - charakteryzują przede wszystkim populację współczesnych i(e)migrantów i mają znaczący wpływ na ich postawy, poglądy oraz stosunek do kraju emigracyjnego i jego społeczeństwa (opinię tę podziela aż 96,1\% ankietowanych). Zdaniem 90,4\% respondentów także diagnoza potrzeb, oczekiwań oraz możliwości i(e)migranta(-tów), prowadzona na różnych etapach procesu przystosowywania się i(e)migranta do życia i funkcjonowania w nowych realiach kraju przyjmującego, winna mieć charakter transkulturowy, tzn. że oprócz typowych standardów profesjonalizmu dla tego typu procedur w naukach społecznych powinna ona uwzględniać rangę uniwersaliów i różnic kulturowych.

Pokłosiem analiz wyników opisanych powyżej badań było opracowanie autorskiego modelu diagnostyki psychopedagogicznej problemów i(e)migranckich o charakterze transkulturowym, który prezentuję poniżej.

\section{MODEL DIAGNOSTYKI PROBLEMÓW I(E)MIGRANCKICH O CHARAKTERZE TRANSKULTUROWYM}

Kryteria profesjonalizmu współczesnych modeli i procedur diagnostycznych wynikają z istoty pedagogiki - nauki wyjaśniająco-diagnostycznej i prakseologicznej, jak również z konieczności podejmowania przez pedagogów i psychopedagogów czynności diagnostycznych będących „aktem odkrywania i identyfikacji” (Advanced Learner's Dictionary, 2000) uwarunkowań badanego zjawiska/ problemu/procesu oraz jego aktualnego stanu i skutków, jakie może wywołać (Radlińska 1935, s. 16; Lisowska, 2003, s. 71; Jarosz, Wysocka, 2006, s. 23). Natomiast konieczność dostosowywania tychże procedur do wymogów współczesności wynika z innowacyjnego charakteru pedagogiki i psychopedagogiki. Istotne znaczenie ma również identyfikacja czynników wpływających na aktualny stan przedmiotu i podmiotu diagnozy (retrognoza), jak również przewidywanie dalszego przebiegu badanego problemu, procesu, zaburzenia - tj. stopnia jego pogłębiania się bądź wygaszania, w sytuacji wdrożenia działań naprawczych albo ich zaniechania (prognoza).

Znaczącym kryterium profesjonalizmu badań diagnostycznych o charakterze transkulturowym w obszarze psychopedagogiki winno być także oparcie tychże badań na założeniach współczesnych teorii transkulturowości, przy jednoczesnym 
respektowaniu siedmiu głównych zasad definiujących profesjonalne badania diagnostyczne w obszarze nauk społecznych, tj. trafności, rzetelności, dogłębności, obiektywizmu, wyczerpywania zakresu niewiedzy oraz bezstronności. Kolejnym kryterium profesjonalizmu opisywanego rodzaju badań jest rozszerzenie ich zakresu do trzech cech charakteryzujących pełną procedurę diagnostyczną, tj. rozpoznania (identyfikacji objawów), rozróżnienia (odróżnienia od siebie objawów podobnych i wytypowania problemu głównego, który będzie przedmiotem dalszych dogłębnych analiz badawczych) oraz oceny diagnostycznej, która winna być jednoznaczna i trafna (Guziuk-Tkacz, 2011, s. 21). Profesjonalizm procedur i badań diagnostycznych wyraża się również w przestrzeganiu przez diagnostę norm i wartości pożądanych w danym obszarze kulturowym oraz zasad etyki zawodowej pedagoga i psychopedagoga (reprezentujących ogólnoludzki system wskazań etycznych dla zawodów pomocowych), do których należą godność zawodu, kompetencje zawodowe, uczciwość, poufność, bezinteresowność, wyczucie, uprzejmość oraz powściągliwość (Tokarczyk, 2009, 77 i in.).

Przy uwzględnieniu powyższego transkulturowe badania diagnostyczne problemów związanych z emigracją mogą przyjąć formę studiów etnometodologicznych, koncentrujących się na badaniu świata przeżywanego i intepretowanego przez członków określonej grupy etnicznej/kulturowej (Guziuk-Tkacz, Siegień-Matyjewicz, 2015, s. 141). W diagnostyce transkulturowej mogą mieć również zastosowanie badania terenowe (prowadzone np. na określonym obszarze, wśród społeczności i(e)migranckiej, w jej w codziennym życiu i podczas wykonywania rutynowych czynności - Guziuk-Tkacz, Siegień-Matyjewicz, 2012, s. 47; 2015, s. 54), jak również badania biograficzne i narracyjne (skoncentrowane na analizie i(e)migranckich biografii/autobiografii, będących odzwierciedleniem przebiegu życia osób badanych lub jego fragmentów, i rejestrowaniu przez nich istotnych zdarzeń - Barker 2005, s. 11; Urbaniak-Zając, 2017, s. 50 i in.). Dużą wartość diagnostyczną tego typu badań podkreślają m.in. antropologowie kultury, ponieważ opowiedziana przez i(e)migranta historia jego życia lub jej fragmenty łączy się zwykle z (typową dla epoki transkulturowości) modyfikacją poczucia własnej tożsamości osobowej i kulturowej badanego, która konstruowana jest przez proces opowiadania i zmienia się w zależności od sytuacji psycho-socjo-kulturowej, w jakiej badana osoba aktualnie się znajduje (Barker, 2005, s. 251). W tego typu procedurach mogą mieć także zastosowanie cztery podstawowe typy studiów indywidualnych przypadków: autoteliczne, instrumentalne, zbiorowe oraz wielokrotne.

Transkulturowy - tj. adekwatny do potrzeb i wymogów współczesności charakter procedur diagnostycznych problemów i(e)migranckich powinien wyrażać 
się także w uwzględnieniu w tego typu procedurach roli i rangi uniwersaliów kulturowych oraz elementów dominujących we wzorze kulturowym osób diagnozowanych, jak również w uznaniu transwersalności ich sądów stanowisk i ocen (Flüchter, Schöttli 2015 i in).

Zgodnie z założeniami teorii transkulturowości w procedurach badawczych istotne jest także uwzględnienie makro- i mikrospołecznego ich charakteru. W ujęciu makrospołecznym czynności diagnostyczne winny być ukierunkowane na rozpoznanie współczesnych problemów, procesów i zjawisk społecznych związanych z migracjami zagranicznymi, takich jak np. transmigracje, translokalność, ponadnarodowe sieci diaspor itp. W ujęciu mikrospołecznym istotna będzie natomiast identyfikacja przyczyn, skutków oraz prognozowanego rozwoju indywidualnych problemów i(e)migranta jako jednostki.

W opisywanym modelu diagnostyki należy również uwzględnić specyfikę poszczególnyh etapów przystosowywania się i(e)migranta do życia i funkcjonowania w nowych realiach psychospołecznych kraju przyjmującego, bagaż osobistych przeżyć i doświadczeń oraz osobliwe cechy reprezentowanego przez niego wzoru kulturowego.

\subsection{TRANSKULTUROWA DIAGNOZA WSTĘPNA}

Transkulturowa diagnoza wstępna prowadzona na początku drogi emigracyjnej powinna uwzględniać aspekt przedmiotowy i podmiotowy czynności diagnostycznych. Mając na uwadze pierwszy z wymienionych aspektów, czynności diagnostyczne trzeba ukierunkować na identyfikację:

$\rightarrow$ wstępnego nastawienia i(e)migranta wobec kraju emigracji i jego społeczeństwa oraz jego uwarunkowań;

$\rightarrow$ najbardziej znamiennych cech wzoru kulturowego reprezentowanego przez i(e)migranta oraz siły związku z krajem pochodzenia;

$\rightarrow$ mocnych i słabych stron osobowości i(e)migranta;

$\rightarrow$ oczekiwań i(e)migranta w stosunku do kraju przyjmującego i funkcjonujących w nim różnorodnych instytucji.

Mając z kolei na uwadze drugi z wymienionych aspektów, czynności diagnostyczne należy ukierunkować na wyodrębnienie:

$\rightarrow$ i(e)migrantów wymagających szczególnej opieki i pomocy;

$\rightarrow$ i(e)migrantów niepełnoletnich wymagających indywidualnych programów dydaktyczno-wychowawczych, opiekuńczych i indywidualnych programów wsparcia. 
Wstępne nastawienie pro- bądź antyintegracyjne wobec kraju emigracji i jego społeczeństwa oraz jego podłoże są funkcją indywidualnych cech osobowości i(e)migranta, jego osobistych doświadczeń i przeżyć, reprezentowanego przez niego wzoru kulturowego oraz przedemigracyjnych wyobrażeń życia i funkcjonowania w tymże kraju. Identyfikacji na tym etapie winny podlegać tzw. czynniki przyciągające (pull factors), które wpłynęły na podjęcie decyzji o wyemigrowaniu i nastawieniu pro- bądź antyintegracyjnym, tj. np. łączenie rodzin, wizja lepszego zabezpieczenia socjalnego, perspektywa wyższych niż w kraju pochodzenia i pewniejszych zarobków, perspektywa osiągnięcia bezpieczeństwa wyznaniowego, możliwość zamieszkania w kraju gwarantującym uchodźcom/ osobom prześladowanym bezpieczeństwo itp. (Kawczyńska-Butrym, 2008, s. 109; Guziuk-Tkacz, 2019, s. 283). Czynności diagnostyczne w tym obszarze powinny być także ukierunkowane na identyfikację pozytywnych schematów poznawczych i(e)migranta, tj. sprzyjających procesowi adaptacji (które winny być realistyczne, zrównoważone i elastyczne) oraz negatywnych, będących konsekwencją bolesnych lub traumatycznych doznań i przeżyć, szczególnie w kontaktach z przedstawicielami innych obszarów kulturowych.

Diagnoza poziomu identyfikacji i(e)migranta z wzorem kulturowym kraju pochodzenia winna być ukierunkowana na oszacowanie siły związku z „krajem wyjścia” oraz na wyodrębnienie i opis głównych i najbardziej znamiennych cech wzoru kulturowego i(e)migranta, takich jak: religia, obyczajowość, zwyczaje, rytuały, stosunek do czasu, pozycja społeczna kobiety i mężczyzny, preferowany system norm i wartości, wzorce reakcji i zachowania itp.

Diagnoza mocnych stron osobowości i(e)migranta, tj. takich, które sprzyjają procesom jego adaptacji i integracji ze społeczeńswtem kraju przyjmującego, winna być ukierunkowana na identyfikację:

- indywidualnych zdolności i potencjału twórczego;

- umiejętności komunikacyjnych, tj. kompetencji językowej i komunikacyjnej;

- wykształcenia, profesjonalnej wiedzy i umiejętności zawodowych (w zawodach pożądanych w kraju emigracji);

- dominacji pozytywnych doświadczeń życiowych nad negatywnymi;

- wysokiego poziomu samooceny,

- inteligencji emocjonalnej (IQ), rozumianej jako kompetencja i(e)migranta do rozpoznawania stanów emocjonalnych własnych i stanów emocjonalnych innych osób w nowych realiach socjo-kulturowych kraju emigracyjnego; 
- kulturowej empatii, wyrażającej się w zdolności do odczuwania stanów psychicznych osób z innych obszarów kulturowych oraz umiejętności przyjmowania ich perspektywy w spotrzeganiu i ocenie rzeczywistości, różnorodnych zjawisk, określonych problemów itp.;

- racjonalnego myślenia, tj. ukierunkowanego na osiągnięcie realnych celów w kraju emigracji;

- dominacji tendencji rozwojowej, połączonej z realną wizją przyszłości nad nierozwojową i koncentracją na przeszłości i teraźniejszości;

- duchowości, wiary w Boga / w Siłę Wyższą (jako formy osobistego wsparcia duchowego i emocjonalnego);

- orientacji prospołecznej (kooperacyjnej, altruistycznej);

- tolerancji inności, odmienności oraz otwartości na nowe wyzwania i doświadczenia (Guziuk-Tkacz, 2019, s. 290-293).

Do czynników osobowościowych, które blokują procesy przystosowawcze i(e)migranta i których identyfikacja tożsama jest z diagnozą słabych stron jego osobowości, zaliczyć należy:

a) zaburzenia psychiczne - wszelkie dysfunkcjonalne wzorce behawioralne lub psychiczne (istotne diagnostycznie jest również ich kulturowe uwarunkowanie);

b) zaburzenia emocjonalne internalizujące (skutkujące wycofywaniem się z kontaktów społecznych, izolacją społeczną, obojętnością bądź niestabilnością uczuciową) oraz zaburzenia emocjonalne eksternalizujące, których skutkiem są destrukcyjne reakcje i zachowania skierowane „na zewnątrz”, takie jak np. nadmierne pobudzenie, akty przemocy itp.;

c) niskie poczucie własnej wartości i niski poziom samodzielności związany np. z postawą oknofiliczną, którą cechuje silne przywiązanie do ludzi i miejsc, złe znoszenie samotności i zmian oraz unikanie nowych wyzwań (Balint, 1959 i in.);

d) dominacja negatywnych doświadczeń życiowych nad doświadczeniami pozytywnymi w zakresie kontaktów kulturowych oraz utrwalone negatywne schematy poznawcze i myślowe;

e) przekonanie i(e)migranta o braku kontroli nad sobą i otaczającą go rzeczywistością oraz pesymizm skutkujący negatywną oceną rzeczywistości społecznej i kulturowej oraz przyszłości;

f) zaburzenia zachowania;

g) uzależnienia chemiczne i behawioralne.

W diagnostyce mocnych i słabych stron osobowości i(e)migranta istotną rolę odgrywa także identyfikacja kompetencji transkulturowych, do których zalicza 
się gotowość do przekraczania granic i „przemieszczania się pomiędzy określonymi problemami współczesności” (Mikołajczyk, 2009, s. 36), akceptację wzorca współistnienia, dialogu i negocjacji (Nikitorowicz, 2001; Welsch, 1998a, 1999), otwartość na „różne formy życia i ramy znaczenia” (Welsch, 1998 b, s. 33) oraz zdolność do wchodzenia na „obszar zróżnicowań, inności i odmienności” (Nikitorowicz, 1995, s. 11).

Diagnoza wstępna, stawiana u progu procesów adaptacyjnych, winna być także skoncentrowana na identyfikacji oczekiwań i(e)migranta w stosunku do kraju przyjmującego i funkcjonujących w nim instytucji opieki, pomocy społecznej, prawa i ochrony (także w kontekście modeli, instytucji i celów polityki azylowej, migracyjnej i readmisyjnej kraju przyjmującego). Jej zadaniem jest również ustalenie stopnia dysproporcji pomiędzy portretem życzeniowym i(e)migranta a rzeczywistością kraju emigracyjnego.

Do grupy i(e)migrantów wymagających szczególnej opieki i pomocy zalicza się osoby, które doznały silnych urazów psychicznych / przeżyły traumę i zdradzają symptomy stresu pourazowego, tj. ofiary tortur, gwałtów, ofiary handlu ludźmi, ofiary wojen $\mathrm{i} /$ lub terroryzmu, osoby ujawniające objawy epizodu depresyjnego, depresji bądź syndromu presuicydalnego. W grupie tej znajdują się również i(e)migranci, których zachowanie i reakcje sugerują choroby psychiczne lub zaburzenia osobowości, osoby przewlekle chore, jak również matki samotnie wychowujące dzieci i osoby powyżej sześdziesiątego roku życia.

Z kolei do grupy i(e)migrantów niepełnoletnich wymagających indywidualnych programów dydaktyczno-wychowawczych i opiekuńczych lub/i indywidualnych programów wsparcia zalicza się osierocone dzieci (sieroty biologiczne lub społeczne), dzieci ze specjalnymi potrzebami rozwojowymi i edukacyjnymi od urodzenia do trzeciego roku życia (SPR) oraz dzieci i młodzież od trzeciego roku życia do ukończenia nauki w szkole (SPE). Do grupy tej zalicza się również dzieci i młodzież, u której stwierdza się występowanie reakcji i zachowań utrudniających bądź uniemożliwiających „prawidłowe funkcjonowanie: ruchowe, sensoryczne, poznawcze, w zakresie komunikacji, emocjonalno-społecznej lub/i psychiczne”2. W grupie tej lokują się również dzieci i młodzież, u której obserwuje się objawy świadczące o zagrożeniu niepełnosprawnością bądź symptomy różnorodnych dysfunkcji, dysharmonii lub niesprawności, mogące mieć negatywny wpływ na dalszy ich rozwój emocjonalny, psychoruchowy, społeczny lub/i poznawczy.

2 Definicje przyjęte przez Zespół Ekspertów ds. Specjalnych Potrzeb Edukacyjnych, powołany w 2008 r. przy MEN. 


\subsection{TRANSKULTUROWA DIAGNOZA ETAPOWA POSTĘPU PROCESÓW PRZYSTOSOWAWCZYCH I INTEGRACYJNYCH I(E)MIGRANTÓW}

Przedmiotem transkulturowych diagnoz etapowych winna być ocena przystosowywania się i(e)migranta do życia i funkcjonowania w nowych realiach kraju przyjmującego. To powód, dla którego badania diagnostyczne w tym obszarze powinny przyjąć formę diagnoz etapowych o charakterze kompleksowym, pełniących funkcję preparacyjną, aktywizującą i informacyjną (tj. diagnoz poznawczych, diagnoz fazy, decyzyjnych, kauzalnych, funkcjonalnych i prognostycznych) opartych na identyfikacji wytypowanych poniżej wskaźników diagnostycznych - symptomów postępu bądź problemów przystosowawczych.

\subsubsection{Wskaźniki diagnostyczne postępu procesów przystosowawczych i(e)migranta w sferze społecznej}

Do grupy wskaźników diagnostycznych świadczących o postępie procesów przystosowawczych i(e)migranta w sferze społecznej zalicza się przede wszystkim zwiększanie częstotliwości i liczby kontaktów społecznych pomiędzy nim a przedstawicielami społeczeństwa kraju przyjmującego oraz intencjonalność tychże kontaktów, jak również stopniowe zdobywanie przez i(e)migranta umiejętności zaspokajania swoich potrzeb psychospołecznych w środowisku kraju emigracji i intencjonalne przyswajanie oraz akceptowanie norm społecznych i kulturowych obowiązujących w tym kraju.

Innymi symptomami postępu w tym obszarze są:

- świadome włączanie się i(e)migranta/-ów do uczestnictwa w życiu społecznym, politycznym i kulturalnym kraju przyjmującego wraz z jego pozytywną oceną;

- angażowanie się i(e)migranta w tworzenie własnej przestrzeni społecznej (Muszyńska, 2013, s. 174) i nowej „sieci społecznej” (Kubitsky, 2012, s. 54), w skład której stopniowo wchodzą obywatele kraju emigracyjnego;

- zamieszkanie w środowisku wielokulturowym, powiązane z opuszczeniem rejonów/gett i(e)migracyjnych;

- umacnianie trwałych więzi społecznych pomiędzy i(e)migrantem a obywatelami kraju przyjmującego;

- stopniowe przyjmowanie i akceptowanie nowych ról społecznych oraz pełnienie ich zgodnie z normami społecznymi, prawnymi i kulturowymi obowiązującymi w kraju emigracji;

- funkcjonowanie i(e)migranta w szeroko rozumianym kontekście społecznym; 
- uznanie tożsamości etnika za tożsamość przejściową;

- odczuwane przez i(e)migranta poczucie skuteczności, powiązane z selekcją rodzajów aktywności w nowym środowisku kraju przyjmującego (Guziuk-Tkacz, 2019, s. 306-308);

- świadome dokonywanie modyfikacji i zmian w zachowaniu oraz funkcjonowaniu społecznym i(e)migranta pod wpływem wyzwań nowego środowiska;

- dążenie i(e)migranta do samorozwoju, poprzez dynamiczne kontakty społeczne.

\subsubsection{Wskaźniki diagnostyczne postępu procesów przystosowawczych i(e)migranta w sferze psychicznej}

O postępie procesów przystosowawczych i(e)migranta związanych ze sferą jego psychiki świadczą następujące wskaźniki diagnostyczne:

- wzrost znaczenia tzw. obiektów przejściowych, którymi są różnorodne przedmioty z kraju pochodzenia, pełniące rolę tzw. pomostów pomiędzy starym a nowym krajem i przygotowujących i(e)migranta do emocjonalnej separacji z krajem pochodzenia (Brettell, 2003 i in);

- uświadomienie sobie przez i(e)migranta różnic kulturowych i ich akceptacja;

- pokonanie szoku kulturowego i związana z tym stopniowa stabilizacja emocjonalna;

- stopniowo coraz sprawniejsze pokonywanie barier psychicznych, takich jak np. bariera lęku przed nieznanym/nowym, przed zmianami, bariera osamotnienia itp.;

- stopniowe przepracowywanie negatywnych przeżyć i doświadczeń związanych z emigracją oraz sukcesywne włączanie ich do bagażu doświadczeń wzmacniających (Kubitsky, 2012, s. 56);

- zastępowanie mechanizmów obronnych mechanizmami adaptacyjnymi (Guziuk-Tkacz, 2019, s. 310);

- umiejętność radzenia sobie ze stresem akulturacyjnym;

- aktywność życiowa i(e)migranta, ukierunkowana na samodzielne zaspokajanie potrzeb psychicznych w nowym środowisku kraju przyjmującego;

- zdolność i(e)migranta do „dokonywania przejść między rozlicznymi konstrukcjami swej tożsamości” (Welsch, 1998b, s. 31);

- przyjmowanie coraz bardziej wyważonej postawy w ocenie kraju emigracji, jego społeczeństwa i funkcjonowania w nim (Kubitsky, 2012, s. 55 i in.); 
- przekonanie i(e)migranta o zyskaniu wiedzy, umiejętności i doświadczeń, pozwalających na prawidłowe funkcjonowanie w kraju emigracji i odczuwanie przez i(e)migranta coraz większej autonomii;

- poczucie samostanowienia oraz zadowolenia i satysfakcji z aktualnego życia;

- dominacja emocji pozytywnych nad negatywnymi;

- dążenie i(e)migranta do stabilizacji, ładu i uporządkowania swojego życia (np. podjęcie stałej pracy) oraz do rozwijania własnych zainteresowań i realizowania osobistych planów (Guziuk-Tkacz, 2019, s. 311);

- brak stanów obniżonego nastroju, stanów depresyjnych oraz zaburzeń emocjonalnych/psychicznych, wywołanych zmianą środowiska.

Wymienione wyżej wskaźniki diagnostyczne postępu procesów przystosowawczych dotyczą i(e)migrantów z różnych grup wiekowych. W przypadku i(e)migrantów niepełnoletnich lub pobierających naukę istotna jest także identyfikacja opisanych poniżej symptomów postępu procesów przystosowawczych i integracyjnych w obszarach powiązanych z nauką, opieką i wychowaniem.

\subsubsection{Wskaźniki diagnostyczne postępu procesów przystosowawczych i integracyjnych w sferze dydaktycznej i opiekuńczo-wychowawczej}

Mając na uwadze wysoką rangę i znaczenie identyfikacji symptomów pozytywnego przebiegu procesów przystosowawczych i integracyjnych dzieci i młodzieży i(e)migranckiej w ramach transkulturowych procedur diagnostycznych prowadzonych przez pedagogów, ustalono następującą listę wskaźników postępu tychże procesów, ukierunkowanych na sferę dydaktyczną i opiekuńczo-wychowawczą.

Do tej grupy objawów zaliczyć należy:

- stopniowe zdobywanie kompetencji językowych i kulturowych;

- postępy w nauce z poszczególnych przedmiotów nauczania, niska absencja na lekcjach i promocje do kolejnych klas;

- ciekawość poznawcza i aktywność własna ucznia/podopiecznego/wychowanka, ukierunkowana na zdobywanie informacji o kraju emigracji, o jego wzorcu kulturowym i wzorcu mentalności, jak również wiedzy na temat obowiązujących w tym kraju norm prawnych, moralnych, społecznych oraz pożądanych form reakcji i zachowania;

- aktywność ucznia/wychowanka, ukierunkowana na zdobywanie wiedzy na temat systemu szkolnego kraju emigracji i ofert edukacyjnych;

- wysoka pozycja socjometryczna ucznia/wychowanka w klasie, w grupie rówieśniczej, brak wzajemnych lub jednokierunkowych antypatii oraz obo- 
jętności pomiędzy członkami społeczności klasowej, grupy rówieśniczej, do której i(e)migrant należy;

- zmniejszenie się dystansu społecznego pomiędzy dziećmi i młodzieżą i(e)migrancką a obywatelami kraju przyjmującego (w różnym wieku);

- bliskie, pozytywne więzi społeczne pomiędzy i(e)migrantem a dziećmi i młodzieżą z różnych obszarów kulturowych oraz otwartość na dalsze tego typu relacje;

- aktywna działalność na rzecz klasy, szkoły, kół naukowych oraz środowiska pozaszkolnego i aktywne uczestnictwo w życiu społecznym kraju przyjmującego (Guziuk-Tkacz, 2019, s. 314-315);

- udana pod względem psychologiczno-pedagogicznym adopcja osieroconych dzieci i(e)migranckich;

- wzrost liczby młodych imigrantów kontynuujących naukę na wyższych szczeblach edukacji - w technikach zawodowych, liceach i na studiach wyższych;

- poczucie samorealizacji, sukcesy zawodowe lub/i naukowe młodych i(e)migrantów (Guziuk-Tkacz, 2019, s. 315).

\subsubsection{Przejawy zintegrowania się i(e)migranta ze społeczeństwem kraju przyjmującego}

Zintegrowanie się i(e)migranta ze społeczeństwem kraju emigracji, będące pozytywnym i pożądanym finałem procesów przystosowawczych, może być analizowane i oceniane z perspektywy:

a) kulturowo-tożsamościowej, związanej z uzyskaniem przez i(e)migrantów kompetencji językowej i kulturowej oraz internalizacją głównych elementów wzoru kulturowego kraju przyjmującego i ich akceptacją, w powiązaniu z poczuciem przynależności do społeczeństwa tego kraju emigracji i utożsamianiem się z nim (Guziuk-Tkacz, 2016, s. 312);

b) transnarodowej - wynikającej z funkcjonowania współczesnych i(e)migrantów w ponadnarodowych przestrzeniach społecznych (Faist, 2000a, 2000b) oraz przynależności do transnarodowych sieci społecznych (Schneiders, $1960 \mathrm{i}$ in.);

c) społecznej - włączanie się i(e)migrantów do struktury społecznej kraju przyjmującego, w powiązaniu z pozytywnymi relacjami i tworzeniem się więzi społecznych w nowym kraju;

d) strukturalno-instytucjonalno-prawnej - wyrażającej się m.in. nabyciem przez i(e)migranta podstawowych praw, jakie przysługują obywatelom kraju emigracyjnego, ostatecznym uregulowaniem statusu pobytu, udziałem/ 
funkcjonowaniem i(e)migrantów w życiu politycznym kraju przyjmującego itp.;

e) ekonomicznej - wyrażającej się m.in. wysokim odsetkiem i(e)migrantów pracujących w kraju przyjmującym zgodnie ze swoimi kwalifikacjami, minimalnymi różnicami lub ich brakiem w dochodach między i(e)migrantami a przedstawicielami społeczeństwa kraju przyjmującego itp. (Guziuk-Tkacz, 2019, s. 319);

Zintegrowaniu się i(e)migranta ze społeczeństwem kraju przyjmującego sprzyjają także indywidualne cechy jego osobowości, do których należą: postawa zaufania, wiary i szacunku do samego siebie, umiejętność kontrolowania swoich emocji, potrzeb i zachowań, umiejętność samoobserwacji oraz introspekcji, obiektywna ocena siebie i swoich możliwości w nowych realiach psychospołecznych oraz niski poziom lęku przed nowymi wyzwaniami. Katalizatorami sukcesów przystosowawczych i integracyjnych są także elastyczność przystosowawcza, sprecyzowane cele życiowe, zawodowe i edukacyjne oraz dążenie do ich realizacji.

Wskaźnikami diagnostycznymi sukcesu procesów przystosowawczych i integracyjnych są również:

$\rightarrow$ poczucie znalezienia się „w zwrotnym punkcie”, od którego i(e)migrant może rozpocząć prawdziwie samodzielne życie, polegające na budowaniu własnej odrębności i konstruowaniu tożsamości osobowej, grupowej i kulturowej w nowym kraju (Guziuk-Tkacz, 2019, s. 320);

$\rightarrow$ uzyskanie kompetencji komunikacyjnej - składającej się z kompetencji lingwistycznej, socjolingwistycznej, pragmatycznej i funkcjonalnej, wyrażającej się pozyskaniem „wiedzy deklaratywnej”’3 w powiązaniu z umiejętnościami uczenia się, stosowania języka kraju emigracji i pożądanego społecznie zachowania się językowego oraz komunikacyjnego;

$\rightarrow$ znajomość i prawidłowe rozumienie symboli składających się na komunikację niewerbalną typową dla wzoru kulturowego kraju emigracji;

$\rightarrow$ określanie kraju emigracji mianem: „dom”, „mój dom”, „moje miejsce na ziemi” i uznanie go za istotny układ odniesienia (Kubitsky, 2012, s. 56);

$\rightarrow$ zdolność i(e)migranta do optymalnego i samodzielnego zaspokajania swoich potrzeb w nowych realiach psychospołecznych;

$\rightarrow$ integracja osobowości w nowym środowisku socjokulturowym;

${ }^{3}$ Por. Europejski System Opisu Kształcenia Językowego (ESOKJ, 2001), wyd. polskie 2003, s. 20; D. Coste, B. North, J. Sheils, J. Trim, Europejski system opisu kształcenia językowego: uczenie się, nauczanie, ocenianie, przekł. W. Martyniuk, Warszawa 2003 (CODN) i in. 
$\rightarrow$ wytyczenie konkretnych celów życiowych w środowisku kraju emigracyjnego i konsekwentne do nich dążenie;

$\rightarrow$ poczucie niezależności i swobody funkcjonowania w kraju przyjmującym, jak również autonomii w myśleniu, odczuwaniu i działaniu (Pytka, Zacharuk, $1995 \mathrm{i}$ in.);

$\rightarrow$ możliwość samorealizacji w „oswojonych” już realiach kraju emigracyjnego;

$\rightarrow$ ustabilizowane/utrwalone poczucie własnej skuteczności w nowym środowisku kraju emigracji;

$\rightarrow$ uzyskanie nowej pozycji społecznej, nowego statusu i miejsca w strukturze społecznej kraju emigracji;

$\rightarrow$ uzyskanie samodzielności finansowej i zatrudnienia w zawodzie odpowiadającym aspiracjom, wiedzy, umiejętnościom i kwalifikacjom i(e)migranta;

$\rightarrow$ posiadanie stałego miejsca zamieszkania w kraju emigracyjnym;

$\rightarrow$ satysfakcja z możliwości swobodnego nawiązywania bezkonfliktowych relacji interpersonalnych w kraju emigracji;

$\rightarrow$ pełne uczestnictwo w życiu społecznym, kulturalnym, gospodarczym i politycznym kraju emigracji (tj. np. otrzymanie prawa głosu), które jest efektem świadomego i indywidualnego wyboru i(e)migranta;

$\rightarrow$ świadome, swobodne i pozbawione postaw roszczeniowych korzystanie ze swoich praw, jak również z określonych świadczeń i usług (Guziuk-Tkacz, 2019, s. 322);

$\rightarrow$ utrwalenie zmian w osobowości i tożsamości i(e)migranta, będących wynikiem modyfikacji osobowości i zachowania na każdym etapie procesu przystosowywania się do życia w nowych realiach kraju emigracji - jako efekt kompromisu, pogodzenia przedemigracyjnej przeszłości z emigracyjną teraźniejszością.

Problemy przystosowawcze, pojawiające się na drodze do integracji i(e)migranta ze społeczeństwem kraju przyjmującego, są konsekwencją kryzysu emigracyjnego, na który składają się szok i(e)migranta (Kubitsky, 2012, s. 37) i szok kulturowy. Zintegrowanie się ze społeczeńwtem kraju emigracji blokują także nieradzenie sobie z pokonywaniem różnorodnych barier psychospołecznych, niemożność poradzenia sobie ze smutkiem, nostalgią, poczuciem osamotnienia i tesknotą za krajem pochodzenia, wzmacniane dysonansem pomiędzy przedemigracyjnym wyobrażeniem kraju przyjmującego a konfrontacją z prawdziwym życiem w tymże kraju.

Wskaźnikami diagnostycznymi, których identyfikacja świadczy o problemach przystosowawczych i(e)migranta w sferze społecznej, psychicznej i edukacyjno- 
-wychowawczej, są objawy przeciwstawne (kontradyktoryczne) do wytypowanych wyżej symptomów wskazujących na postęp adaptacyjny i integracyjny. Z tego też powodu pominięto ich wyliczenie.

Z kolei wskaźnikami porażki procesów adaptacyjnych i integracyjnych jest nieprzystosowanie społeczne i(e)migranta, manifestujące się nieumiejętnością przystosowania się do życia i prawidłowego funkcjonowania w kraju emigracji, ciągłą dezorientacją w środowisku emigracyjnym, nieumiejętnością rozwijania swoich zainteresowań i realizowania planów w nowym środowisku oraz niemożliwością osiągnięcia stanu równowagi pomiędzy potrzebami psychospołecznymi i(e)migranta a wymaganiami „nieoswajanego” przez wiele miesięcy, a nawet lat, środowiska (Paleczny, 2007, s. 165). Kryzysy przystosowawcze manifestują się także: częstym uruchamianiem mechanizmów i strategii obronnych, przyjmowaniem postaw roszczeniowych wobec kraju emigracji i jego społeczeństwa, zachowaniami agresywno-przemocowymi, autoagresją, biernością i izolacją społeczną, niewypełnianiem ról społecznych, niekorzystaniem z zasobów publicznych, konfliktami z prawem oraz radykalizacją postaw antyspołecznych, rasistowskich i ksenofobicznych, jak również nadużywaniem alkoholu i środków psychoaktywnych.

Mając powyższe na uwadze w diagnozie problemów i(e)migranckich o charakterze adekwatnym do potrzeb współczesności - tj. transkulturowym, oprócz zasad regulujących jej profesjonalizm (takich jak np.: trafność, rzetelność, dogłębność, obiektywizm, wykorzystanie różnorodnych źródeł wiedzy itp.) uwzględnić należy również: wagę poszczególnych faz procesów adaptacji i integracji i(e)migranta, symptomatykę postępu oraz blokad tychże procesów, rangę elementów wzoru kulturowego reprezentowanego przez podmiot diagnozy oraz znaczenie uniwersaliów i różnic kulturowych w relacjach diagnosta - osoba diagnozowana.

\section{Bibliografia}

Advanced Learner's Dictionary. (2000). New York: Oxford University Press.

Balint, M. (1959). Thrills and regressions. London: The Hogarth Press.

Barker, Ch. (2005). Studia kulturowe. Teoria i praktyka. Tłum. A. Sadza. Kraków: Wydawnictwo Uniwersytetu Jagiellońskiego.

Bauman, Z. (1988). Prawodawcy i tłumacze. Tłum. A. Ceynowa, J. Giebułtowski. Warszawa: Wyd. Instytutu Filozofii i Socjologii PAN.

Brettell, C. (2003). Anthropology and migration. Lanham: AltaMira Press.

Faist, T. (2000). The Volume and Dynamics of International Migration and Transnational Social Spacer. Oxford: Oxford University Press. 
Faist, T. (2000). Transnationalization in international migration: implications for the study of citizenship and culture. Ethnic and Racial Studies, 23(2).

Flüchter A., Schöttli, J. (red.). (2015). The Dynamics of Transculturality - Concepts and Institutions in Motion. Heidelberg: Springer.

Guziuk-Tkacz, M., Siegień-Matyjewicz, A.J. (2012). Leksykon terminów metodologicznych. Warszawa: Wyd. Akademickie Żak.

Guziuk-Tkacz, M., Siegień-Matyjewicz, A.J. (2015). Leksykon pedagogiki międzykulturowej i etnopedagogiki. Warszawa: Wyd. Akademickie Żak.

Guziuk-Tkacz, M. (2019). Imigracja(e) i imigranci w kontekście transkulturowości. Diagnoza pedagogiczna. Olsztyn: Wyd. UWM.

Jarosz E., Wysocka, E. (2006). Diagnoza psychopedagogiczna. Podstawowe problemy i rozwiqzania. Warszawa: Wyd. Akademickie Żak

Kawczyńska-Butrym, Z. (2008). Migracja: Perspektywa mikrospołeczna - indywidualne i rodzinne zyski, koszty i straty. W: M.St. Zięba (red.), Migracja - wyzwanie XXI wieku. Studia nad migracja, t. I. Lublin: KUL

Kostyrko, T. (2012). „Transkulturowość” w ujęciu André Malraux - przyczynek do pojmowania terminu. W: J. Kubitsky (2012). Psychologia migracji. Warszawa: Wydawnictwo Diffin.

Lisowska, E. (2003). Wprowadzenie do diagnozowania pedagogicznego. Kielce: Wydawnictwo Wszechnica Świętokrzyska.

Maśloch, P. (2005). Globalizacja i jej wpływ na rozwój współczesnej cywilizacji. Przedsiębiorczość a współczesne wyzwania cywilizacyjne. Przedsiębiorczość - Edukacja, 1.

McGrew, A. (1992). Conceptualizing Global Politics. W: A. McGrew (red.), Global Politics. Cambridge: Polity Press.

Mikołajczyk, H.T. (2009). Rozum transwersalny, czyli o postmodernistycznym rozumieniu racjonalności. Słupskie Studia Filozoficzne, 8.

Misiejuk, D. (2018). Koncepcje społeczne a standard wielokulturowości. Kultura i Edukacja, 3(121),

Muszyńska, J. (2013). O wspólnotach lokalnych i ich znaczeniu - rozważania pedagoga. W: M. Sobecki, W. Danilewicz, T. Sosnowski (red.), Szkoła - kultura - tożsamość. Pedagogika społeczna wobec zmian przestrzeni życia społecznego. Warszawa: Wyd. Akademickie Żak.

Nikitorowicz, J. (1995). Pogranicze. Tożsamość. Edukacja międzykulturowa. Białystok: Wydawnictwo Uniwersyteckie Trans Humana.

Nikitorowicz, J. (2011). Edukacja międzykulturowa w kontekście dylematów integracji imigrantów w warunkach wielokulturowości. W: A. Paszko (red.), Edukacja międzykulturowa w Polsce wobec nowych wyzwań. Kraków: Stowarzyszenie Willa Decjusza.

Nikitorowicz, J. (2015). Człowiek transkulturowy jako efekt dialogu tożsamościowego. W: A. Kieszkowska (red.), Prawda, dobro, piękno. Wymiar filozoficzno-prawny i socjopedagogiczny. Warszawa: Wydawnictwo Diffin.

Okólski, M. (2009). Polska jako aktor na europejskiej scenie migracyjnej. W: M. Duszczyk, M. Lesińska (red.), Współczesne migracje. Dylematy Europy i Polski. Warszawa: Wydawnictwo UW. 
Paleczny, T. (2007). Interpersonalne stosunki międzykulturowe. Kraków: Wydawnictwo Uniwersytetu Jagiellońskiego.

Pytka, L., Zacharuk, T. (1995). Zaburzenia przystosowania dzieci i młodzieży. Aspekty diagnostyczne i terapeutyczne. Siedlce: Wyższa Szkoła Rolniczo-Pedagogiczna.

Radlińska, H. (1935). Stosunek wychowawcy do środowiska społecznego. Szkice z pedagogiki społecznej. Warszawa: Nasza Księgarnia.

Sobecki, M. (2018). Wielowymiarowe poczucie tożsamości społeczno-kulturowej. Idea i badanie. Perspektywa pedagogiczna. Kultura i Edukacja, 3(121).

Steingress, G. (2010). Globalizing cultures: a challenge for contemporary cultural sociology. Eurasian Journal of Anthropology, 1(1).

Tokarczyk, R. (2009). Etyka prawnicza. Warszawa: LexisNexis.

Urbaniak-Zając, D. (2017). Narracja a biograficzna perspektywa badawcza. Nauki o Wychowaniu. Studia Interdyscyplinarne. Studia i Rozprawy, 1(4).

Welsch, W. (1995). Transkulturalität. Zur veränderten Verfaßtheit heutiger Kulturen. Zeitschriftfür Kulturaustausch, 1.

Welsch, W. (1998a). Transkulturowość. Nowa koncepcja kultury. W: R. Kubicki (red.), Filozoficzne konteksty rozumu transwersalnego. Wokół koncepcji Wolfganga Welscha, cz. II. Poznań: Wydawnictwo Fundacji Humaniora.

Welsch, W. (1998b). Stajq̨ się sobq. W: A. Zeidler-Janiszewska (red.), Problemy ponowoczesnej pluralizacji kultury. Wokół koncepcji Wolfganga Welscha, cz. I. Poznań: Wydawnictwo Fundacji Humaniora.

Welsch, W. (1999). Transculturality. The Changing Forms of Cultures Today. W: The Contemporary Study of Culture, Bundesminister für Wissenschaft und Verkehr \& Internationales Forschungszentrum für Kulturwissenschaften. Wien: Turia\& Kant.

Wilkoszewska, K. (red.). (2004). Estetyka transkulturowa. Kraków: Wydawnictwo Universitas. 